\title{
STUDIES IN THE METABOLISM OF ATROPHIC INFANTS *
}

\author{
CHARLES A. FIFE, M.D., AND BORDEN S. VEEDER, M.D. \\ PHII_ADELPHIA
}

The value of a food for an infant depends, in the broadest sense, on two factors: on the one hand, whether or not the food meets the requirements of the organism in furnishing sufficient energy and material for growth, and on the other, whether or not the food itself, or the substances derived from it in the process of digestion, exert any deleterious action on the organism.

Fundamentally associated with the first problem is the question of absorption of the food in the gastro-intestinal canal. In our system of infant feeding in which the percentage of protein, fat and carbohydrate in the food is the criterion by which we judge of its suitability, and by which we modify the mixture according to the clinical manifestations, it is important to know whether the absorption of the different substances is influenced by the percentage relation of one to another. Very few observations have been made on this point. The following studies on atrophic infants were undertaken with the purpose of determining the ahsorption of fat under the influence of different proportions of fat and carbohydrate, and the influence of the varying quantities of fat and carbohydrate on the nitrogen metabolism.

The methods used were as follows:

The infants were given a definite formula for periods of at least six days, and during the last three days of each period the urine and feces were completely collected. The fat and nitrogen content of the food was determined each day during the periods by analysis. As the carbohydrate excretion was not considered, the sugar intake was not accurately determined, but was computed from the average found in many previous analyses of milk, plus the amount of a 1 per cent. lactose solution added to bring the formula to the desired strength. As will be seen later, it was only necessary to know the approximate quantity of sugar, i. e., whether the sugar percentage was high or low. The urine was preserved by chloroform and kept on ice until the three-day specimen was completed. The total three-day specimen of feces was evaporated to dryness in the usual manner. By using a three-day period after giving the same formula from three to six days previously, the chances of error from irregular excretion,

* From the William Pepper Clinical Laboratory, University of Pennsylvania.

* Read before the meeting of the American Pediatric Society, Lake Mohonk, N. Y., June, 1911. 


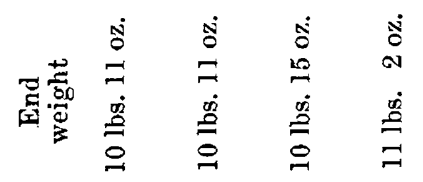

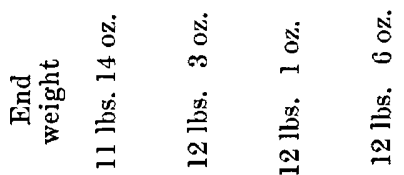

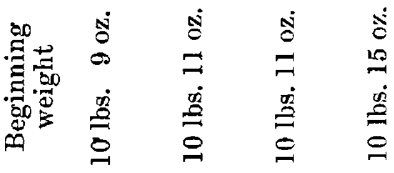

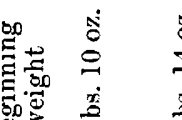

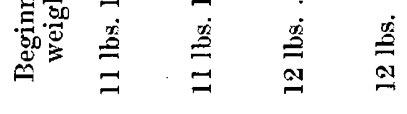

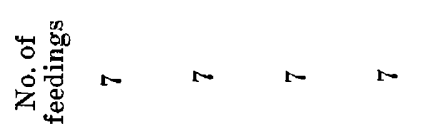

胥

울

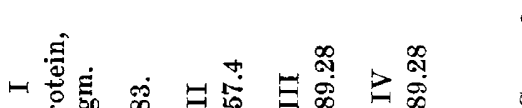

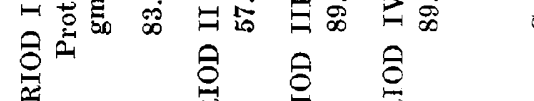

$\mathrm{H}$

$\therefore$ क

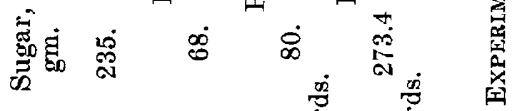

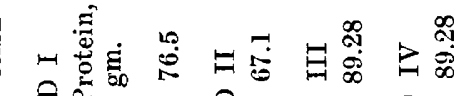

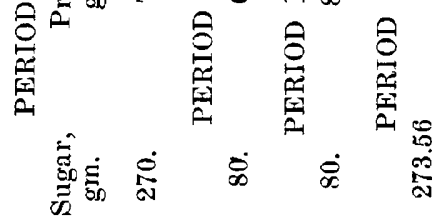

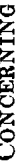

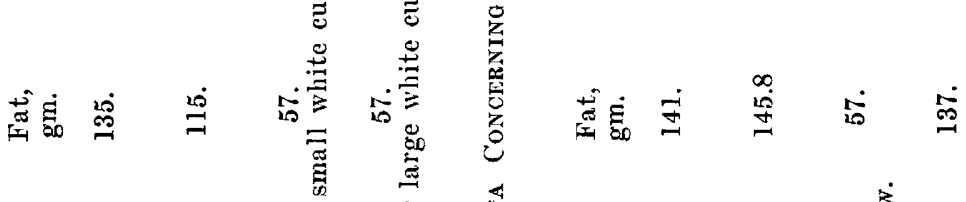

?.

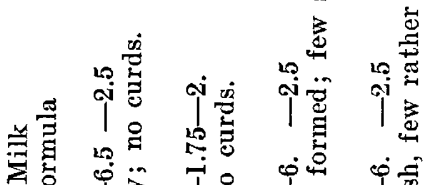

离

낭

它焉 $N$ N

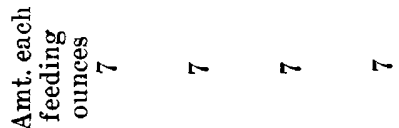

ㅇ. 要出

䁏

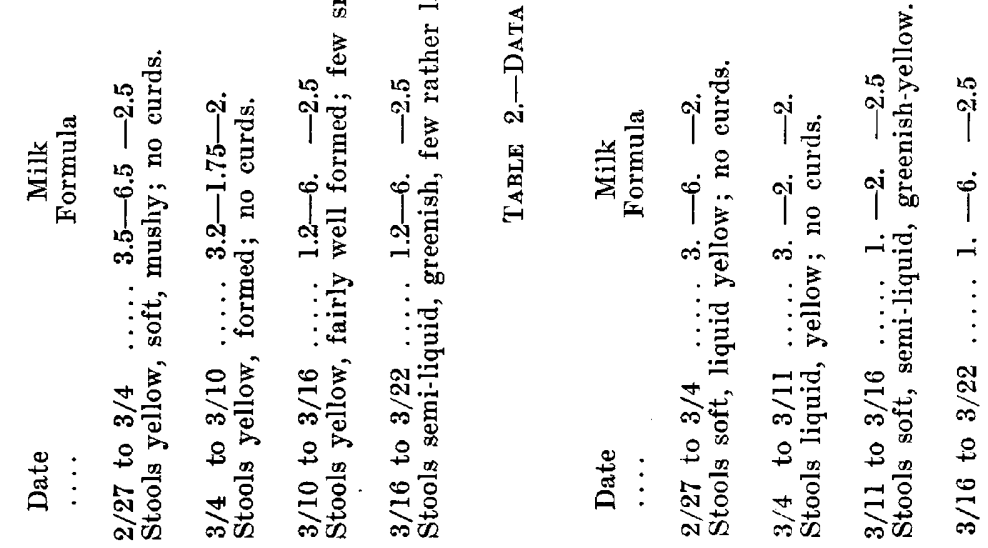


as at times occurs in twenty-four-hour specimens, are largely eliminated. It is to be especially noted that the figures throughout represent the combined total of three consecutive days and not the daily intake or excretion. ${ }^{1}$

The histories of the cases studied and the notes of the different periods are as follows:

\section{CASE REPORTS}

CASE 1.-Albert H., white, aged 9 months, was admitted to the hospital early in January for acute bronchitis, which cleared in a few days; previous history of gastro-enteritis and malnutrition; bottle-fed (milk modifications unknown) since shortly after birth; father tuberculous and mother mentally deficient. On admission the child weighed 10 pounds, 7 ounces, and at the time of beginning the studies was nine months old and weighed 10 pounds, 8 ounces. During the intervening two months the weight remained almost stationary, although numerous milk modifications were tried. The stools were soft, greenish or yellow in color and contained occasional curds. Physical examination showed a child with flabby musculature and little adipose tissue; cannot sit alone; length 25 inches; circumference of head 16 inches; circumference of chest $15 \frac{1}{2}$ inches; circumference of abdomen 15 inches; anterior fontanelle open, measures $11 / 1 \times 11 / 2$ inches; superficial lymph-nodes slightly palpable; slight beading of the ribs; heart and lungs negative; abdomen soft and not distended; reflexes normal.

CASE 2.-Edward, white, aged 10 months, was admitted to hospital January 8 for diarrhea and loss of weight, with a previous history of malnutrition with loose and offensive stools. The child was bottle fed after two months; had diphtheria at four months followed by discharging ear; family history negative. On admission he weighed 10 pounds, 10 ounces. Under treatment the ear condition improved and the stools became much better in character, being as a whole yellow in color and smooth, with only oceasional curds. The weight curve was fluctuating and between the time of admission and the first period the net gain was only one pound; age at time of beginning studies (Feb. 27), 10 months; weight 11 pounds, 10 ounces. Physical examination showed slightly rachitic, atrophic infant, with flabby musculature. He could hold his head upright, but could not sit alone.

Circumference of head 17 inches, chest 15 inches, abdomen $16 \frac{1}{2}$ inches. Anterior fontanelle open-1 inch in width; heart and lungs negative; liver slightly enlarged; umbilical hernia; posterior cervical lymph-nodes enlarged; reflexes normal.

\section{FAT ABSORPTION}

The work that has been done on the absorption of fats in infants is a difficult subject to review and correlate. There are apparently many discrepancies in the results of the studies of fat metabolism that have been published, which we believe in the first place depend largely on the methods used. Kumagawa and Sutro ${ }^{2}$ have recently studied this question, using known quantities of fat, and find considerable differences in

1. Fat in the milk was determined by the Leffman-Beam method and nitrogen by Kjeldahl. The nitrogen of the urine and of the feces was determined by the $\mathrm{Kjeldahl}$ method, and $\mathrm{Ca}$ by the method of MeCrudden. In the fat extraction from the feces the method of Brugsch was used, which permits of a separation of the soaps from the neutral fats and fatty acids.

2. Kumagawa and Sutro: Biochem. Ztschr., 1908, viii, 337. 
the results obtained by several of the methods in common use. They have worked out a method which gives the most accurate results for total quantities of fat, but which does not permit of a separation of the fat in the feces into its component parts; i. e., neutral fats, fatty acids, and soaps. This is of considerable importance in the study of the feces in infancy, as it is supposed to bear an intimate relation to the question of the diseases of salt metabolism (rachitis, tetany, exudative diathesis, etc.). While the method we used gives results which probably vary from 5 to 10 per cent. from the total quantity of fat, the same error is carried throughout, and as the studies are comparative in nature this error is of little importance. It is also difficult to contrast the results of one worker with those of another, for although the studies as a whole are numerous, the conditions under which they have been undertaken differ considerably and the investigations are few in which any one point or question has been under consideration. A normal breast-fed or artificially-fed infant absorbs the larger part of the ingested fat. Bahrdt, ${ }^{3}$ in the most recent and careful studies that have been made, using the Kumagawa method, finds an absorption of 93 per cent. in the normal child. A few years ago Freund ${ }^{4}$ reviewed the various studies on fat absorption and from these and others since published it may be concluded that the normal absorption in a healthy infant lies between 90 and 95 per cent. The figures outside of these limits published as "normal" are probably due to either faulty methods or to disturbances in absorption. In both acute and chronic nutritional disturbances absorption of fats in the intestine is lowered, from 10 to 50 per cent. or more of the amount ingested being found in the stool. Practically all of this fat is derived directly from the food, a very small amount of ether-extractable substances being found in the stool with a fat-free diet. The loss of fat in nutritional disturbances is due to several factors, as altered digestion, accelerated peristalsis, admixture with mucus, etc. In our own cases the loss was from 15 to 33 per cent. of the quantity ingested. There is some question as to the form in which the fats are absorbed from the intestinal canal, but it is the generally accepted view that they must be split before absorption and are then recombined in the cells of the intestinal mucosa.

Our problem, however, did not deal so much with the question of how much was absorbed, or the form in which it was absorbed, as with the question of the absorption of large and small quantities of fat, and the influences of varying quantities of carbohydrate on the absorption of the fat. The accompanying table (Table 3 ) summarizes our results as regards the first question.

3. Bahrdt: Jahrb. f. Kinderh., 1910, lxxi, 249.

4. Freund: Ergebn. d. inner. Med. u. Kinderh., 1909, iii, 38. 
Table 3.-Showing the Percentage of Fat Loss in the Two Experimental Cases During the Four Periods

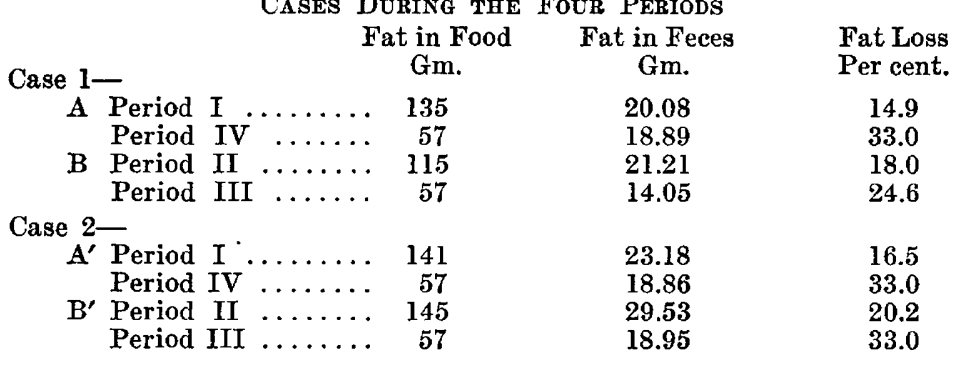

When large quantities of fat are given the actual amount of fat in the stool is increased but the percentage absorption is much better. Average figures show this clearly.

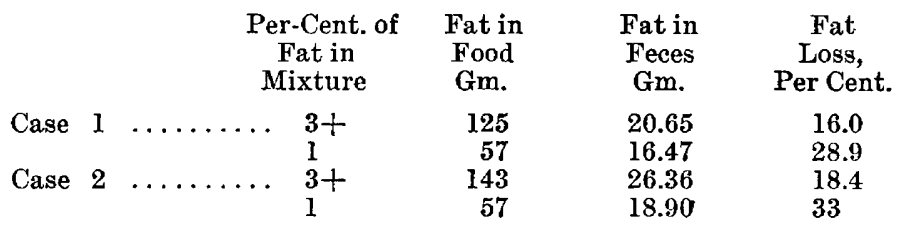

In the 3 per cent. mixtures nearly five-sixths of the ingested fat was absorbed, while in the 1 per cent. mixtures a third was passed in the stool. Or, looking at it from another view-point, although there was about two and one-half times as much fat present in the food in the high fat periods, the feces contained only half again as much as in the low fat periods.

Somewhat similar results were obtained by Hecht $t^{5}$ in a 12-months-old child in two three-day experiments :

\begin{tabular}{|c|c|c|c|}
\hline & $\begin{array}{c}\text { Fat in Food } \\
\text { Gm. }\end{array}$ & $\begin{array}{c}\text { Fat in Feces } \\
\text { Gm. }\end{array}$ & $\begin{array}{l}\text { Fat Loss } \\
\text { Per cent. }\end{array}$ \\
\hline Period I & 89.28 & 4.929 & 5.3 \\
\hline Period II & 10.26 & 1.662 & 16.3 \\
\hline
\end{tabular}

In this case, however, there was considerable stimulation of the intestinal mucosa when the low fat was given (Milchmalzsuppe made with Magermilch). During this period the child passed from five to six liquid stools daily and the two investigations may have different interpretations although similar in results. L. F. Meyer ${ }^{6}$ likewise observed a difference in proportion between the fat intake and the loss in the feces (normal child) :

\begin{tabular}{|c|c|c|c|}
\hline & $\begin{array}{c}\text { Fat in Food } \\
\text { Gm. }\end{array}$ & $\begin{array}{c}\text { Fat in Feces } \\
\text { Gm. }\end{array}$ & $\begin{array}{l}\text { Fat Loss } \\
\text { Per Cent. }\end{array}$ \\
\hline 1. $\ldots \ldots \ldots \ldots \ldots$ & 10.97 & 0.8 & 2.29 \\
\hline 2. $\ldots \ldots \ldots \ldots \ldots$ & 35.95 & 1.588 & 4.44 \\
\hline $3 . \quad \ldots \ldots \ldots \ldots \ldots$ & 44.3 & 1.75 & 3.95 \\
\hline
\end{tabular}

5. Hecht: Wien. klin. Wchnschr,, 1907, xx, 497.

6. Meyer, L. F.: Biochem. Ztschr., 1908, xii, 422. 
Freund ${ }^{4}$ gives a similar comparison between normal infants:

\begin{tabular}{|c|c|c|c|}
\hline & $\begin{array}{c}\text { Fat Ingested } \\
\text { Daily, } \\
\text { Gm. }\end{array}$ & $\begin{array}{l}\text { Fat in } \\
\text { Feces } \\
\text { Gm. }\end{array}$ & $\begin{array}{c}\text { Fat } \\
\text { Loss, } \\
\text { Per Cent. }\end{array}$ \\
\hline \multicolumn{4}{|l|}{ Experiment 1- } \\
\hline Period I . & 3.93 & $0.446 \mathrm{~S}$ & 14.27 \\
\hline Period II & 16.50 & 2.4160 & 14.64 \\
\hline \multicolumn{4}{|l|}{ Experiment 2- } \\
\hline Period I. & 3.17 & 0.5785 & 18.25 \\
\hline Period II & 15.90 & 2.25110 & 14.21 \\
\hline
\end{tabular}

In this case the fat loss in the feces bears the same percentage relation, with high and low fat intake. There are so many points of difference (age, method, time, etc.) between our observations and those of Freund that we do not wish to draw conclusions from a comparison between the two.

As fat and carbohydrate differ from protein, in that they may be substituted for one another within certain limits, as both are energy and heat producers rather than tissue builders, we combined high and low carbohydrate diets with the fats in order to determine whether the amount of carbohydrate exerted any influence on the absorption of fats. Thus in Table 3 in the periods grouped under $A$ and $A^{\prime}$ the food contained a high (6) percentage of sugar. In those grouped under $\mathbf{B}$ and $\mathrm{B}^{\prime}$ the food contained a relatively low ( 2 per cent.) amount. The total amounts are given in the accompanying Table 4. Table 4.- High and Low Carbohydrate Diets Combined with Fats to Deter-
Mine Influence of Carbohydrates on Fat Absorption Case 1-

A Period I

Period IV $\ldots \ldots \ldots \ldots \ldots .273$

Case 2-

$A^{\prime}$ Period $\mathrm{I} \ldots \ldots \ldots \ldots .270$

Period IV .........273

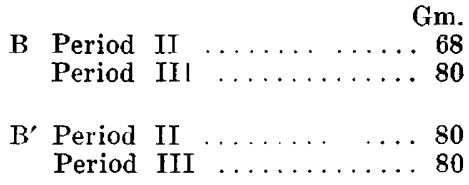

Gm.

Contrasting $\mathrm{A}$ with $\mathrm{B}$, and $\mathrm{A}^{\prime}$ with $\mathrm{B}^{\prime}$ in Table 3 , and considering the marked difference in the amount of carbohydrates in these periods, we are unable to find any apparent influence of the amount of carbohydrate on the absorption of the fat. Practically the same relation holds between the intake and absorption of large and small quantities of fat no matter whether a large or a small quantity of carbohydrate is present in the food.

As the quantity of nitrogen (see Table 6) in the food was nearly the same in all of the periods the explanation of these changes then must lie in the digestion of the fat itself. In no period was there a diarrhea present which might have accounted for the conditions. Moreover, the tolerance for or ability to absorb fat does not seem to be affected. In Case 1 there was an absolute absorption of $115 \mathrm{gm}$. of fat in Period I, while in Period IV the total quantity given was only $57 \mathrm{gm}$., of which a third $(18.86 \mathrm{gm}$.$) , was found in the stool, only 1.2 \mathrm{gm}$. less than in the 
first period. A similar condition was present in Case 2. In none of the periods was the so-called "soap stool" of Czerny's "milk injury" or Finkelstein's "balance disturbances" present. We investigated, however, the question of soaps and calcium excretion and the results are shown in Table 5 .

Table 5.-Showing Determinatiox of Soaps and Calcicm

\begin{tabular}{|c|c|c|c|c|c|}
\hline & $\begin{array}{c}\text { Milk } \\
\text { Formula } \\
\ldots \ldots\end{array}$ & $\begin{array}{l}\text { Fat in } \\
\text { Stools } \\
\text { Gm. }\end{array}$ & Soap & $\begin{array}{c}\text { Soaps } \\
\text { Per } \\
\text { Cent. }\end{array}$ & $\mathrm{Ca}$ \\
\hline $\begin{array}{c}\text { Case } 1 \text { Period I } \\
\text { Ped }\end{array}$ & $3.5-6-2.5$ & 2008 & 257 & 123 & 3.54 \\
\hline Period II & $3.2-2-2$ & 21.21 & 2.00 & 9.4 & 2.51 \\
\hline Period III & 1. $-2-2.5$ & 14.05 & 6.13 & 43.6 & 2.51 \\
\hline Period IV & 1. $-6-2.5$ & 18.89 & 6.30 & 33.3 & 3.95 \\
\hline \multicolumn{6}{|l|}{ Case 2- } \\
\hline Period I & 3. $-6-2$. & 23.18 & 3.58 & 15.2 & 3.54 \\
\hline Period II & 3. $-2-2$. & 29.53 & 2.29 & 7.4 & 4.21 \\
\hline Period III & 1. $--2-2.5$ & 18.95 & 10.66 & 56.2 & 3.72 \\
\hline Period IV & 1. $-6-2.5$ & 18.86 & 9.90 & 52.5 & 3.74 \\
\hline
\end{tabular}

In both cases the absolute quantity of soaps was about three times more in the low fat periods than in the high, and the relative amount was increased on an average nearly five times. The amount of Ca excreted in the feces bears no relation to the absolute amount or relative proportion of soaps. If in these cases the infants were atrophic as a result of fat injury, the high fat periods should have shown the higher amounts and percentages of soaps. An explanation on these grounds, then, is wanting. Birk and Rothberg thought the formation of fat stools depends on the withdrawal of the earthy alkalies through their combination with fat, and they see in this withdrawal the cause of the failure to gain weight in this condition. Freund contends that the amount of soap formation depends on the reaction of the stool, which in turn depends on the bacterial changes producing fermentation when large amounts of sugar are present. A study of Table 5 shows that in Periods I and II, with a high and a low sugar intake, the soap formation was low, and that in periods III and IV, with a low and a high sugar intake, the amount of soap is high, averaging 48 per cent. (Case 1) and 54 per cent. (Case 2) of the total quantity of fat in the stools. Moreover, the amount of $\mathrm{Ca}$ in the feces does not bear any relation to the amount of soaps present, whether we compare it with the actual amounts of soap or the percentage relation to the total amount of fat.

We must conclude, then, that the changes are due to certain unexplained factors and that they do not support any of the above mentioned studies on fat metabolism in chronic nutritional disturbances.

\section{NITROGEN METABOLISM}

The second part of the study took up the question of the nitrogen metabolism under varying fat and carbohydrate percentages and in this we have confined ourselves to the nitrogen retention. It is a generally 
accepted fact that the amount of nitrogen in the feces is not proportionate to nor dependent on the amount of nitrogen in the food, although when jncreasing the food nitrogen from a very low or hungering period there is an increase of nitrogen in the feces. In investigations made by Kellar ${ }^{7}$ on fasting infants an excretion of nitrogen in the feces of .0716 gm. and of $.097 \mathrm{gm}$. in twenty-four hours was found after a preliminary period of thirty hours. In artificially fed infants the nitrogen amounts from 2 per cent. to 6 per cent. of the total weight of the dried feces. ${ }^{8}$ Very little if any of the ingested nitrogen of the proteins is excreted as such although some of the nitrogen occurs in the form of their cleavage and putrefactive products. This together with the nitrogen of the gastrointestinal juices and secretions, bacteria and epithelial cells, constitute the sources of the nitrogen of the feces. Although not directly dependent on the ingested food, it may be modified to some extent by the action of the food in stimulating or retarding the secretion of the gastro-intestinal juices, as the observations of Wohlgemuth and others have shown. It is very probable that, as in the case of $\mathrm{Ca}$ salts, the nitrogen absorbed may be excreted and reabsorbed in the intestinal canal. A glance at Table 6 shows no evident relation between the varying percentages of the food elements and the amount of nitrogen in the feces (i. e., nitrogen absorption). In Case 1 the amount varies from $1.345 \mathrm{gm}$. to $2.460 \mathrm{gm}$., while in Case 2 it is uniformly about $2.5 \mathrm{gm}$. in all four periods. For these reasons a study of the absorption is of little or no value and the important question is the study of the nitrogen retention. The nitrogen intake and the output in the urine and feces is shown in Table 6 . The balance is considered as retained nitrogen, no account having been taken of the amount excreted through the skin. This is a small factor and in all probability would have been parallel throughout the periods in each case. So far as we know the only studies that have taken this into account are those of Rubner and Heubner, ${ }^{9}$ and Tangl. ${ }^{10}$ The former found a loss of $0.189 \mathrm{gm}$. of nitrogen per day in a normal child and $0.0338 \mathrm{gm}$. in an atrophic infant, while the latter found an excretion of 0.044 in an artificially-fed infant.

The nitrogen retention may be studied in two ways, either the total percentage retention (Nutzungswerth) or the retention per kilo of body weight. The figures for the lacter (last column, Table 6) have been divided by three so as to give the retention per kilo per twenty-four hours, in order to compare our figures with those of previous studies. It will be noted that in all of our periods the retention of nitrogen was very good. The nitrogen intake in all of the periods was higher than was

7. Kellar: Arch. f. Kinderh., 1900, xxix, 123.

8. Hecht: Die Feces des Säuglings, 1911, p. 24.

9. Rubner and Heubner: Ztschr. f. Biol., 1899, xxxviii, 315.

10. Tangl: Arch. f. d. ges. Physiol., Bonn (Pflüger), 1904, clv, 453. 
Tale 6.- Showing Nitrogen Intake and OUtput in the Ubine and Feces

\begin{tabular}{|c|c|c|c|c|c|c|}
\hline $\begin{array}{l}\text { Period } \\
\ldots \ldots \\
\ldots \ldots\end{array}$ & $\begin{array}{l}N \text { in } \\
\text { Food }\end{array}$ & $\begin{array}{l}N \text { in } \\
\text { Feces }\end{array}$ & $\begin{array}{l}N \text { in } \\
\text { Urine } \\
\ldots \ldots\end{array}$ & $\begin{array}{c}\text { N Re- } \\
\text { tained } \\
\ldots . .\end{array}$ & $\begin{array}{l}\text { Per Cent } \\
\text { of } N \\
\text { Retained }\end{array}$ & $\begin{array}{l}\text { Retention } \\
\text { per Kilo } \\
\text { per } 24 \mathrm{Hrs}\end{array}$ \\
\hline \multicolumn{7}{|l|}{ Case 1- } \\
\hline & 13.460 & 1.345 & 5.080 & 7.035 & 52.2 & .482 \\
\hline II & 9.185 & 1.418 & 5.174 & 3.593 & 39.2 & .246 \\
\hline III & 14.285 & 1.968 & 7.812 & 5.505 & 38.8 & 370 \\
\hline IV & 14.285 & 2.460 & 6.506 & 5.239 & 36.6 & .349 \\
\hline \multicolumn{7}{|l|}{ Case 2- } \\
\hline I & 12.243 & 2.144 & 4.340 & 5.759 & 47.0 & .351 \\
\hline II & 10.722 & 2.550 & 5.660 & 2.512 & 23.4 & .152 \\
\hline III & 14.285 & 2.438 & 6.930 & 4.917 & 34.4 & .298 \\
\hline IV & 14.286 & 2.610 & 4.700 & 6.975 & 48.8 & .416 \\
\hline
\end{tabular}

necessary for the development and replacement of the body tissues. Although it was our intention to have the nitrogen intake the same in all periods, the total amount by analysis was less in Period 2 in each case. In both of these periods the absolute retention is less although the percentage retention in Case 1 is practically the same as in Periods III and IV. It is evident that an increase of the nitrogen in itself leads to increased retention, but this opens a question which is outside of the scope of the paper. The highest percentage and best absolute retention is found in the high carbohydrate periods ( $\mathrm{I}$ and IV). This is seen clearly in Case 2 in which the retention in the high periods averages 48 per cent. and 29 per cent. in the low. In Case 1 it is less marked as the difference between the averages is only 5.4 per cent., although Period I shows the highest percentage retention of all-over half of the ingested nitrogen being retained in the body. This is not due to insufficient calories in the food in the low carbohydrate periods, as between 75 and 80 calories per kilo were present in the food in Period III, which is the lowest period from the standpoint of calories. This observation is in accordance with those of Kellar and of Orgler. Orgler ${ }^{11}$ studied the influence of lactose and saccharose on the nitrogen retention in a normal child and his results are summarized as follows:

\begin{tabular}{|c|c|c|c|c|}
\hline $\begin{array}{l}\text { Food } \\
\ldots\end{array}$ & $\begin{array}{c}\text { Food-N } \\
\ldots \ldots\end{array}$ & $\begin{array}{l}\text { Urine-N } \\
\ldots \ldots\end{array}$ & $\begin{array}{l}\text { Balance } \\
\ldots . . .\end{array}$ & $\begin{array}{l}\text { Per Cent. } \\
\text { Retained }\end{array}$ \\
\hline $300 \mathrm{gm}$. milk . & 1.7748 & 1.2853 & +0.229 & 12.9 \\
\hline $\begin{array}{l}250 \mathrm{gm} \text {. malzsuppe } \ldots \\
10 \mathrm{gm} . \text { lactose } \ldots . .\end{array}$ & & . & & \\
\hline $\begin{array}{l}10+50 \mathrm{gm} \text {. lactose. } \\
10+50 \mathrm{gm} \text { saccharose }\end{array}$ & $\begin{array}{l}1.6743 \\
1.8272\end{array}$ & $\begin{array}{l}.6824 \\
.8369\end{array}$ & $\begin{array}{r}+0.583 \\
+0.663\end{array}$ & $\begin{array}{l}34.8 \\
3.3\end{array}$ \\
\hline
\end{tabular}

Kellar's ${ }^{12}$ case is less conclusive, as the kind of food was completely changed, although the carbohydrates were markedly increased and the nitrogen remained practically the same:

11. Orgler: Jahrb. f. Kinderh., 1908, lvii, 383.

12. Kellar: Malzsuppe, eine Nahrung für Magendarmkranke Säuglinge, Jena, 1908. 


$\begin{array}{ccccc}\text { Food } & \text { Food-N } & \text { Urine-N } & \text { Balance } & \begin{array}{c}\text { Per Cent. } \\ \text { Retained }\end{array} \\ \ldots \ldots & \ldots \ldots \ldots & \ldots \ldots & \ldots \ldots & 9.9 \\ 1 / 2 \text { milk c.mm. water } & 2.6725 & 2.0274 & -0.2646 & 9.9 \\ \text { Malzsuppe } \ldots \ldots \ldots & 2.3443 & 1.4463 & -0.417 & 17.8\end{array}$

As regards the quantity of fat in the food, we may simply state that as far as these observations show it is without apparent influence on the nitrogen retention. In comparing the nitrogen metabolism of the atrophic infants with that of healthy artificially-fed infants we find a paucity of studies suitable for such purposes as a result of the variations in body weight and in the kind and amounts of foods used. The best suited for this purpose may be taken from Hoobler's ${ }^{13}$ study of a nine months' infant weighing about 8 kilos. Three periods of three days each with a high, medium and low fat percentage, with a nitrogen intake of $20.7 \mathrm{gm}$., $21.6 \mathrm{gm}$., and $25.5 \mathrm{gm}$., respectively, were studied.

The nitrogen retention per kilo of body weight per day was as follows :

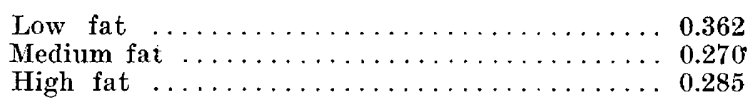

Hoobler found that about 33 per cent. was retained in each of the periods; in other words, the amount of fat was of little influence. He thought the retention of nitrogen was not influenced by the amount ingested-a conclusion we do not feel is justified by his studies. Hoobler does not give the percentage of carbohydrate in his milk mixtures, but it is probable that they contained about 6 per cent. as is customary in most of the milk mixtures in this country. Comparing our periods of high (6 per cent.) sugar with his we find a much higher percentage retention as well as a better absolute retention:

\begin{tabular}{|c|c|c|}
\hline & Case 1 & Case 2 \\
\hline $\begin{array}{l}\text { Period I } \\
\text { Period IV }\end{array}$ & $\begin{array}{l}.482 \\
.349\end{array}$ & $\begin{array}{l}.351 \\
.416\end{array}$ \\
\hline
\end{tabular}

The better nitrogen retention of the atrophic infants may be due to their beginning on a period of convalescence, as both children started in to improve from the moment they were placed on the metabolic bed in the first period.

\section{SUMMARY}

In the study of these two cases of infantile atrophy-the results of which are similar-the following conditions were noted:

The fat absorption was less than in normal infants, although the infants were able to absorb large quantities of fat.

The percentage absorption was better with a large amount of fat in the food than with low amounts.

13. Hoobler: Arch. Pediat., 1910, xxvii, 853. 
The amount of carbohydrate in the food did not influence the fat absorption.

The amount of fat in the form of soaps in the feces was neither proportional to the amount of calcium in the feces nor to the amount of the carbohydrate in the food.

Both the actual and percentage amounts of soaps were greater when the fat intake was low.

The nitrogen retention was greater than in normal infants of the same age and weight.

Increasing the amount of the carbohydrate produced an increased nitrogen retention, but the nitrogen retention was not influenced by the amount of fat in the food.

2033 Locust Street. 